\title{
The Readability of the Management Discussion and Analysis Section and Footnotes of 10-Ks: The Case of the Gas and Oil Industry
}

\author{
Alan B. Czyzewski \\ Indiana State University \\ Kelly Wilkinson \\ Indiana State University \\ Mary Czyzewski \\ University of Alabama
}

The Gas and Oil industry, of which individuals own 65.5\% of the stock, is a key sector of the U.S. economy. (Shapiro and Pham, 2014) Readable information on this industry is important to the U.S. economy and individuals particularly regarding retirement fund decisions. Determining the reading level of the Management Discussion and Analysis Section (MDA) and footnotes of the 10-K for the oil and gas industry is the purpose of this study. The MDAs' average Flesch Index was 12.93. The footnotes' average Flesch Index was 12.57. Given these scores and the average reading level of adults most are unable to understand them.

Keywords: Readability, Flesch Index, Oil and Gas

\section{INTRODUCTION}

The Gas and Oil industry is a key sector of the U.S. economy. It provides 10.3 million job, 5.6\% of all U. S. jobs and was 7.6\% of the U.S. GDP in 2015. (API, 2017) Individuals own $65.5 \%$ of the U.S. Gas and Oil company stock. (Shapiro and Pham, 2014) Because of perceived familiarity of the industry based on use of products, age of industry, and visibility of research and development, there is interest in investing in the industry as noted by the amount of individual ownership of gas and oil stock.

Since the oil and gas sector contributes significantly to the U.S. economy the readability of its documents could have a major impact on individuals' investing. Because of the age of the oil and gas industry along with the its global presence; the industry is an attractive investment for all investors Individuals, U.S. and foreign investment firms, pension funds, government funds, major industrial companies and banks are looking at oil and gas to deliver consistent profits and with increased need, guaranteed growth, (Why Invest in Oil and Gas, n.d.). 


\section{Changes in Retirement Plans}

As people are asked to make their own financial decisions; whether it be in stock trading or retirement management, readability becomes an important issue. Individuals are "reading" documents they may not be able to understand due to complex language and industry lingo, (Czyzewski \& Wilkinson, 2014). This change in investment culture can provide an increased impetus for change in the investment document language including accounting documents.

As firms move from defined benefit retirement plans towards defined contribution plans, it has become increasingly important nonprofessionals be able to understand financial documents. A disparity was found between investor type and their use of information. (Arnold, Bedard, Phillips, and Sutton (2010). Gaps in the use of information between professional and nonprofessional investors are shown in Table 1. Professional investors use footnotes $(68 \%)$ while nonprofessional investors use them lesser rate $(30 \%)$, the largest gap between professional and non-professional investors. Is readability a factor in this gap between professional and nonprofessional investors when they are analyzing footnotes for decision making?

The oil and gas industry also carries with it significant risks which can affect the industries financial statements as well as their attractiveness with investors. Price volatility, dividend cuts, and oil spill risk can affect the oil and gas profits. Financial documents that are readable are a "must" so all investors can make well informed investment decisions, (Edwards, 2015).

The ability to read and understand financial material is an essential for the professional investor to be successful. For many of these professionals, this knowledge comes not only from certification and/or a college degree steeped in financial minutia, but also from focused experience, and/or training that deals with often quite complex financial data. A higher than average reading level is an expectation to obtain this knowledge. (The Princeton Review, n.d.).

\section{Governing Bodies' Concerns Regarding Readability}

Readability of all documents is a common concern and focus within the public and private environment. The SEC issued A Plain English Handbook in 1998. In the preface Warren Buffett issued a cautionary warning in stating:

Perhaps the most common problem, however, is that a well-intentioned and informed writer simply fails to get the message across to an intelligent, interested reader. In that case, stilted jargon and complex constructions are usually the villains. (SEC, (1998)) 
TABLE 1

WHAT INFORMATION DO INVESTORS USE?

\begin{tabular}{|c|c|c|c|c|}
\hline & \multicolumn{2}{|c|}{$\begin{array}{l}\text { Percentage viewing at least one } \\
\text { category item }\end{array}$} & \multicolumn{2}{|c|}{$\begin{array}{l}\text { Mean number of items viewed within } \\
\text { category }\end{array}$} \\
\hline & $\begin{array}{l}\text { Investment } \\
\text { Professionals }\end{array}$ & $\begin{array}{l}\text { Nonprofessional } \\
\text { Investors }\end{array}$ & $\begin{array}{l}\text { Investment } \\
\text { Professionals }\end{array}$ & $\begin{array}{l}\text { Nonprofessional } \\
\text { Investors }\end{array}$ \\
\hline $\begin{array}{l}\text { All annual } \\
\text { report categories }\end{array}$ & $100 \%$ & $99 \%$ & 32.8 & 15.7 \\
\hline $\begin{array}{l}\text { Financial } \\
\text { Statements }\end{array}$ & $94 \%$ & $68 \%$ & 5.3 & 2.4 \\
\hline $\begin{array}{l}\text { Financial } \\
\text { Statement } \\
\text { Footnotes }\end{array}$ & $68 \%$ & $30 \%$ & 4.4 & 1.7 \\
\hline $\begin{array}{l}\text { Auditor and } \\
\text { Management } \\
\text { Reports }\end{array}$ & $70 \%$ & $60 \%$ & 1.7 & 1.3 \\
\hline $\begin{array}{l}\text { Management } \\
\text { Discussion \& } \\
\text { Analysis }\end{array}$ & $85 \%$ & $59 \%$ & 6.2 & 2.3 \\
\hline $\begin{array}{l}\text { Business Data } \\
\text { and Risk Factors }\end{array}$ & $97 \%$ & $82 \%$ & 10.6 & 5.4 \\
\hline $\begin{array}{l}\text { Other Required } \\
\text { Information }\end{array}$ & $58 \%$ & $37 \%$ & 2.7 & 1.5 \\
\hline $\begin{array}{l}\text { Summary } \\
\text { Information } \\
\text { from Company } \\
\text { Website }\end{array}$ & $99 \%$ & $79 \%$ & 1.9 & 1.1 \\
\hline
\end{tabular}

Source: Arnold, Bedard, Phillips, and Sutton (2010)

The federal government continued to address readability with The Plain Writing Act of 2010, which purpose: "to improve the effectiveness and accountability of Federal agencies to the public by promoting clear government communication that the public can understand and use, (H.R. 946). At the state government level, thirty-nine states have laws concerning the readability of insurance contracts, (Hansen, n.d.)

The private sector tackled readability of documents by instituting guidelines to improve readability. The National Association of Insurance Commissioners formed a Transparency and Readability of Consumer Information Committee in 2010, (National Association of Insurance Commissioners [NAIC], 2016). One purpose of the committee is to: "Promote consistent, clear and logical formatting and organization of all policies; and any other measures that would improve the intellectual accessibility of policy forms" (National Association of Insurance Commissioners [NAIC], 2016).

Financial Accounting Standards Board (FASB) is currently working on a disclosure framework with objectives "to improve the effectiveness of disclosures in notes to financial statements by clearly communicating information that is most important to users of each entity's financial statements, " (March 11, 2016). FASB specifically states the purpose of the framework is to: "...provide guidance to improve the organization, formatting, and style of notes to financial statements." The framework does not use the term readability, but the implication is there. 
Even these highly trained professional investors struggle to read financial documents, as most disclosure statements do not meet states' readability standards, and companies' compensation discussions and analyses do not meet the accepted readability standards.

While professional investors struggle to read financial documents, the general population has an even harder time interpreting financial documents due to the lack of financial literacy; since financial literacy is incredibly difficult to acquire without basic literacy. Reading, which requires the ability to obtain, process, and understand information, is necessary for becoming a successful investor, and if one cannot read, it makes educating oneself far more difficult, creating a sort of vicious cycle of ignorance that is expensive to correct, (Czyzewski \& Wilkinson, 2014)

The general population's ability to gather critical information to make financial decisions may be affected by their reading level. Thus, the question is: does the reading ability of most U.S. citizen match with the reading level of the information used to make financial decisions; and does the reading level of financial information appropriate for the general populations' reading level.

\section{PURPOSE}

To determine the reading level of Management and Discussion Analysis Section (MDA) of Gas and Oil 10-Ks is the purpose of this study. Since the "average person" is now being asked to become an expert regarding their retirement decisions, the MDA Section is becoming more important information to the general population rather than just to the financial analysts.

The following questions are addressed in the study:

1. Is the MDA Section's readability significantly higher than the U.S. populations' average reading level?

2. Is the readability of footnotes significantly higher than the U.S. populations' average reading level?

\section{LITERATURE REVIEW}

\section{Oil and Gas Sector}

The focus of this paper is the readability of oil and gas MDAs and footnotes. The energy sector is an attractive and volatile investment with a significant economic impact. In 2009, 5.3 percent, 9.2 million, of all jobs were in oil and gas. Pension and mutual funds had significant portions of their portfolios in this industry, 27 percent and 29.5 percent respectively. Gas and oil had value added of $\$ 1.1$ trillion, 7.7 percent of the U.S. Gross Domestic Product in 2009. Also, six percent of all wages in the U.S., \$533 billion were in the gas and oil industry, (Bagai, 2010). In 2014 individual investors who were not company executive or directors owned 65.5 percent of the shares in the industry. Individual investors directly own 18.7 percent of the shares. Also, 46.8 percent of the shares are owned indirectly in IRAs, pension plans, and 401(k)'s. Middle class households dominate publicly held oil and gas firm ownership. (Shapiro and Pham, 2014)

As individual investors are required to become more involved in investing particularly for retirement, investors may look at familiar companies and products, ("How to Choose a Stock,", 2011). Due to the age of the industry as well as the extensive use of the products, the Oil and Gas Industry serves the purpose.

\section{Need for Financial Literacy for Managing Retirement Funds}

Individual investors increasingly need to be able to understand financial documentation as the responsibility of investing retirement dollars shift from expert financial advisors to the individual investor. As firms are moving from defined benefit retirement plans towards defined contribution plans, it becomes increasingly important that nonprofessionals be able to understand financial documents.

Defined contribution and defined benefit plans were customarily managed by professional money managers with $60 \%$ of workers who had a private pension plan in 1993 said their primary plan was a 
defined contribution plan (US Department of Labor, 1994). Both 401 (k) plans and individual responsibility in managing pension portfolios have grown, but according to an Employee Benefit Research Institute (1996) survey, the majority of working Americans have a limited amount of knowledge regarding financial retirement issues, like planning and savings.

The Boston College Center for Retirement Research found that defined benefit plans decreased from $60 \%$ of workers in 1981 with a pension plan to $10 \%$ in 2003. Defined contribution plans went from $20 \%$ in 1981 to just over 60\% in 2003 (Buessing and Soto, 2006). This was to a large degree perpetuated by FASB 87 "Employees Accounting for Pensions" (Issued in December of 1985). To avoid recording large pension liabilities on their FASB 87-required balance sheets, firms moved away from defined benefit plans; in 1994, General Motors had approximately \$54 billion in various retirement liabilities out of a total of $\$ 185$ billion in liabilities on its balance sheet, while at the same time, the stockholders' equity was approximately $\$ 12$ billion.

The current literature indicates that people require more financial literacy, as they have a greater and greater part in making their own investment decisions, and there are two possible ways to achieve that: 1) increase people's knowledge or reading abilities, as the general population only reads at the eighth grade level, or 2) write financial documents in a way the general population can understand (Kirsch, Jungeblut, Jenkins, and Kolstad 1993 and Winslow and Jacobson, 1998). Many entities have opted for the second way and are trying to write at a level understandable by the general public, including credit card companies (Prater, 2010), Institutional Review Boards or IRBs (Paasche-Orlow, Taylor, and Branati, 2003), and State Insurance Commissions (Carr, March 29, 2010). The reason many entities have chosen the second way is because attempts at the first way, increasing the general population's reading ability, have not been successful; the average reading level in the United States, despite various efforts, has not increased (Gifford, 2007).

\section{Dealing with Financial Information Complexity}

The growing number of SEC regulations has caused the complexity of financial information to increase significantly. Accountants, analysts, and lawyers alike have questioned whether there is any benefit to the length and complexity of the statements, as the financial information is not being written for ease of reading and understanding, but rather to comply with rules. Even Arthur Radin, managing partner of Radkin, Glass, \& Company LLP, stated, "I have to admit that while I am paid to read the 10-K's of the public companies my firm audits, and it is my responsibility, it ain't easy," (Radin, 2007 p. 8). If a managing partner struggles to read financial documents; how difficult is it for the individual investor to understand.

In 1998, the Security and Exchange Commission (SEC) issued "The Plain English Rule" (Rule 421(d)) to deal with the language complexities of financial documents. This rule, which requires plain English in the forepart of prospectuses and encourages it in other financial disclosures, entails: no legal jargon, no multiple negatives, active voice, tables for complex information, everyday language, and short sentences. In the forward of "A Plain English Handbook," Arthur Levitte, then SEC Chairman, noted: "Because many investors are neither lawyer, accountant or investment bankers, we need to start writing discloser documents in a language investors can understand" (p.3). If investors cannot understand complex documents, or if companies can use vague language to hide disadvantageous information, it could lead to capital market in efficiency, (SEC, 1998).

Rule 421(d) encourages the use of the "Plain English" guidelines in the financial statements. Footnotes commonly state that "The accompanying notes are an integral part of these statements," and then go on to clarify and expand upon the Balance Sheet, Income Statement, and Statement of Cash Flows. For example, the additional information might include a description of the accounting methods that were used, or simply more details,(SEC, 1998).

Addressing the concerns of readability of their own documents, the insurance industry governing body, the NAIC, formed the Transparency and Readability of Consumer Information Working Group in 2010. One charge to this group was to: ". . . facilitate consumers" capacity to understand the content of insurance policies and assess differences in insurers' policy forms," (National Association of Insurance 
Commissioners, 2016 p.8) In examining this charge the Working Group considered: Implementing new readability rules as suggested by the Market Regulation and Consumer Affairs Committee; "Promoting consistent, clear and logical formatting and organization of all policies; and any other measures that would improve the intellectual accessibility of policy," (National Association of Insurance Commissioners, 2016 p.8)

The NAIC is trying to improve the readability of insurance documents by providing "the Value of More Readable Documents". Their guidelines include the following statements:

- "Even Americans with good literacy skills appreciate improved readability.

- Most Americans could read beyond the $8^{\text {th }}$ grade level, but they likely won't. Most Americans read below their grade level; many high school graduates read at the $8^{\text {th }}$ grade level.

- The reader can concentrate on the message instead of being distracted by complicated language.

- The rapid expansion of what consumers need to know increases the value of better communication.

- Clear communication increases trust. (Cude, 2010)

More readable insurance documents would allow consumers to better consumers. Most states, (39) have laws regarding a defined reading score for insurance policies. Most states set a Flesch score of 40, a few require higher scores, to ensure effective readability for the major of U.S. citizens.) The industry recognizes there is a need for easier to read material, (Hansen, n.d.)

\section{Readability}

Multiple studies have revealed startling statistics regarding basic literacy skills in the United States. U.S. adults have, on average, an eighth grade reading level, and approximately $20 \%$ read at or below the fifth grade level; this is nowhere near the level required to earn a living wage (Griswould, 2008; Know your readers, n.d). This inadequacy in literacy costs taxpayers and businesses about $\$ 20$ billion per year, and also harms the people who lack those literacy skills (The truth about literacy in the United States, n.d.).

Due to a lack of basic literacy skills, $43 \%$ of people over 16 could not enroll in postsecondary education. Since expert financial analysts are educated beyond the postsecondary level, this means that $43 \%$ of people do not have the skills they need to gain the financial knowledge necessary to make decisions about their retirement.

Three elements typically identify readability: legibility, interesting, and ease of understanding (Jones and Shoemaker, 1994). Of the many different readability scales that each measure readability this study uses two: the Flesch Index and the Flesch-Kincaid Index. The Flesch Index uses the average number of syllables per word and words per sentence to compile a score; the higher the score, the easier it is to read the document. For standard documents, the Flesch Index score should be 60 or 70, while many states' insurance departments require by law that insurance policies have a minimum score of 40 to 50 . (Hansen, n.d.). Table Two shows the comparison of Flesch Index scores to the education level required to read a document with that score.

TABLE 2 COMPARISON OF FLESCH INDEX SCORES TO GRADE LEVEL

\begin{tabular}{ll}
\hline Score & Grade Level \\
\hline 0 to 30 & College Graduate \\
30 to 50 & 13 to 16 grades \\
50 to 60 & 10 to 12 grades \\
60 to 70 & 8 and 9 grades \\
70 to 80 & 7 grade \\
\hline
\end{tabular}

Source: Adapted from Flesch, R. (1949). The art of readable writing. New York: Harper. P.149 
The Flesch-Kincaid Index is derived from the Flesch Index, and although they both use word and sentence length as core measures, the weighting factors are different, resulting in an inverse relationship between the results of the two tests. If a document has a comparatively high score on the Flesch Index Test, it should have a lower score on the Flesch-Kincaid. (Kincaid, Fishburne, Rogers, \& Chissom, 1975). A variety of industries use both of these indexes to evaluate the readability of documents. The FleschKincaid and Flesch Indexes as two of the three models used by the SEC to measure readability metrics of financial information (Cox, 2007).

\section{METHODOLOGY}

Gas and Oil Companies were selected from 310 firms within 11 different SIC codes were selected at random from the Edgar Database, which contains approximately 90,000 firms from a period of 16 years, (see Table Three). The 10-Ks from the selected firms were downloaded, and the MDA and Footnotes sections were cut and pasted onto separate Word documents. Then, Word (from Office 2003 Suite) Spelling and Grammar Check was run on each of these files. The researchers then collected and compiled the following information from each file: Flesch-Kincaid Grade Level, Flesch Reading Ease Score, Passive Sentences Percent, Word Count, Number of Paragraphs, Number of Sentences, Sentences per Paragraph, and Words per Sentence.

The hypotheses for the study were:

$\boldsymbol{H}_{1}$ : The readability of MDA Section significantly exceeds the average Reading level of the U. S. population.

$\mathrm{H}_{2}$ : The readability of footnotes significantly exceeds the average Reading level of the U. S. population.

For $\mathrm{H}_{1}$ and $\mathrm{H}_{2}$, a one sample t-test was run, using the average reading level of the U.S. population, which is $8^{\text {th }}$ grade, as independent variable. The one sample t-test was performed using both the Flesch Index score and the Flesch-Kincaid score as the independent variable.

TABLE 3

\section{SIC CODES USED IN STUDY}

\begin{tabular}{ll}
\hline 1311 & Crude Petroleum and Natural Gas \\
1381 & Drilling Oil and Gas Wells \\
1382 & Oil and Gas Field Exploration Services \\
1389 & Oil and Gas Field Services, NEC \\
2911 & Petroleum Refining \\
2950 & Asphalt paving and Roofing Materials \\
2990 & Miscellaneous Products of Petroleum and Coal \\
3533 & Oil and Gas Field Machinery and Equipment \\
4922 & Natural Gas Transmission \\
4923 & Natural Gas Transmission and Distribution \\
4924 & Natural Gas Distribution \\
\hline
\end{tabular}

\section{RESULTS}

Table Four contains descriptive information based on the readability measures which included passive sentences, words per sentence, sentences per paragraph, total sentences, total paragraphs, and total words. These variables are all part of the Flesch Index and the Flesch-Kincaid Index.

For the MDA sections, the average Flesch Index reading level was 12.93, indicating that they are very difficult to read (See Table Four). The average Flesch Index reading level for the footnotes was 12.57 , indicating that they are also very difficult to read. Significant differences was found between the 
readability of the MDA and Footnotes sections for the Oil and Gas firms at .01 (see Table Five) and the reading level of the general population. At the .01 level, significant differences were also found between the Flesch and Flesch-Kincaid scores of the MDA and Footnotes sections and the general population. For the general population, scores of 65 for the Flesch Index and eight for the Flesch-Kincaid Index were used.

\section{TABLE 4}

\section{DESCRIPTIVE DATA FOR VARIABLES MDA AND FOOTNOTES}

\begin{tabular}{lcc|ccc}
\hline Variable & Minimum & Maximum & Mean & Standard Deviation \\
\hline Flesch Index & 0 & 31 & 12.93 & 5.845 \\
Flesch Kincade & 13 & 21 & 17.44 & 1.176 \\
Passive Sentences & .10 & .57 & .2678 & .06096 \\
Words per Sentence & 3 & 33 & 24.65 & 3.022 \\
Sentences per Paragraph & 2 & 55 & 4.31 & 3.965 \\
Total Sentences & 15 & 3132 & 294.78 & 343.358 \\
Total Paragraphs & 1 & 6959 & 392.51 & 775.597 \\
Total Words & 380 & 88969 & 8173.55 & 9904.006 \\
\hline Descriptive Data for Variables Footnotes & \multicolumn{5}{|c}{} \\
\hline Variable & Minimum & Maximum & Mean & Standard Deviation \\
\hline Flesch Index & 0 & 34 & 12.57 & 7.133 \\
& \multicolumn{5}{|c}{} \\
Flesch Kincade & 14 & 24 & 17.40 & 1.401 \\
Passive Sentences & 0.0 & .45 & .1868 & .05187 \\
Words per Sentence & 10 & 31 & 23.61 & 2.797 \\
Sentences per Paragraph & 2 & 14 & 3.59 & 1.156 \\
Total Sentences & 26 & 3260 & 387.87 & 417.393 \\
Total Paragraphs & 32 & 14852 & 965.26 & 1597.287 \\
Total Words & 749 & 100598 & 11434.46 & 12504.015 \\
\hline
\end{tabular}

\section{DISCUSSION}

For the MDA sections, the average Flesch Index reading level was 12.93, indicating that they are very difficult to read (See Table Four). The average Flesch Index reading level for the footnotes was 12.57, indicating that they are also very difficult to read. When compared to the average reading level for the U.S. population, this means that a large portion of the population cannot read and understand either the MDA or footnotes sections of 10-Ks.

Based on average reading levels of U.S. adults, $43 \%$ of the U.S. population are unable to do the following:

1. reading and understanding moderately dense, less commonplace prose texts as well as summarizing, making simple inferences, determining cause and effect, and recognizing the author's purpose.

2. locating information in dense, complex documents and making simple inferences about the information.

3. locating less familiar quantitative information and using it to solve problems when the arithmetic operation is not specified or easily inferred."(Kutner, Greenberg, Jin, Boyle, Hsu, and Dunleavy, 2007). 


\section{TABLE 5}

\section{INDEPENDENT T-TEST RESULTS BY READABILITY SCORE OF FLESCH INDEX AND FLESCH-KINCADE INDEX MDA AND FOOTNOTES}

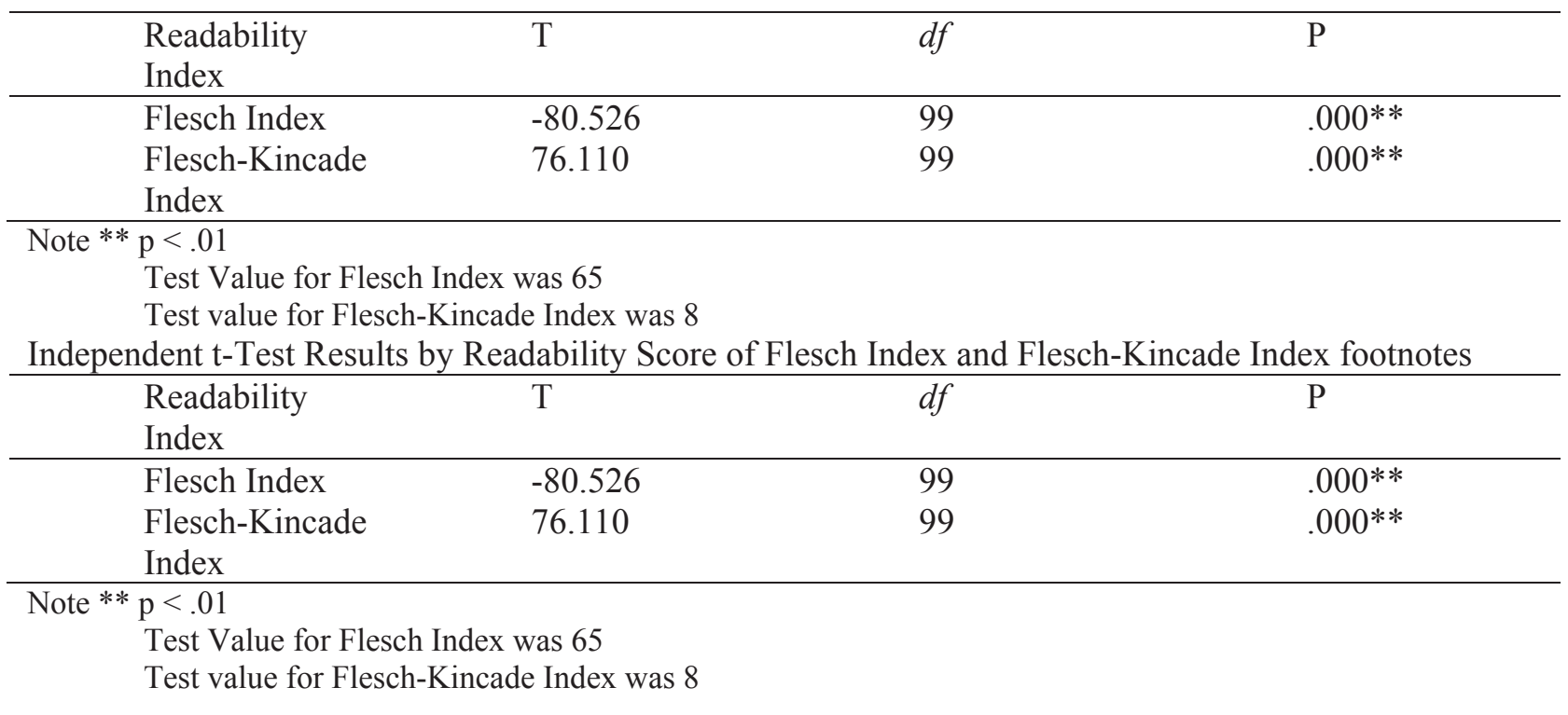

While in the past, "experts" made decisions regarding the general population's retirement, people are increasingly being asked to make these decisions themselves. This change is prompted by the shift to defined contribution plans from defined benefit plans requiring individuals to become experts in ascertaining worthwhile retirement investments (AARP, 2007). A higher than average reading level is an important part of the expert's sophisticated financial training, gaining financial literacy is essential for the general public so they can make better, more informed investment decisions.

In order for the general population to attain financial literacy, they must first have basic literacy so that they can further educate themselves. Education is one of two ways to increase the general population's ability to understand financial documents, and the other is for entities to make financial documents easier to read. Since previous attempts to improve the general population's reading level have been unsuccessful, it would seem that rewriting financial documents at an easier reading level would be both more attainable and successful (Gifford, November 19, 2007). The ability of the general population to read and understand financial information is important, but it's especially important when the documents concern the gas and oil industries, since they form such a large part of the economy, and since a large portion of the gas and oil industries is owned by individuals.

Both the MDA and Footnotes sections are vital in communicating the financial health of an entity, and writing them in "legal jargon and obtuse language" makes people mistrustful and less likely to invest (Loughran \& McDonald, 2013).

While only future research will determine whether the MDA and Footnotes sections can be rewritten at a lower reading level, the Texas Office of Consumer Credit Commissioner's (TOCCC) work (n.d.) with various documents, including home equity loan contracts, would seem to indicate that it can be done. The TOCCC's website contains examples of both traditional and plain English documents. The plain English version of a home equity loan has a high Flesch Reading Ease score of 77.8 and contains 42 words while the traditional home equity loan consists has a very low Flesch Reading Ease score of 13.9 and 139 words.

If rewriting a home loan can improve the Flesch from 13.9 to 77.8 , it would seem not only possible but probable that the MDA and footnotes could also be rewritten at an easier reading level, making them easier for the general population to understand. The other option for making financial documents easier to understand would be to increase the general population's reading level, which it seems would be much 
more difficult than rewriting the footnotes and MDA, as the effort to increase the reading level of the general population has not been successful. More readable footnotes and MDAs would lead to a greater level of understanding on the part of the general population, and thus to better investment decisions.

It also seems there should be more of a focus on communication regarding MDA and footnotes. The purpose of both items is to communicate meaning to the reading. It seems the opposite is true. A curriculum change may be needed for accountants and other influencers of MDA and footnote writers. Future research may be warranted regarding the time and money spent (or not spent) regarding the education and training of good writing for accountants.

\section{REFERENCES}

American Association of Retired People. (2007). Preparation for retirement: The haves and have-nots. AARP. Retrieved from http://assets.aarp.org/rgcenter/econ/retirement_prep.pdf.

American Petroleum Institute. (2017). Impacts of the Natural Gas and Oil Industry on the US Economy in 2015. Retrieved from https://www.api.org/ /media/Files/Policy/Jobs/Oil-and-Gas-2015Economic-Impacts-Final-Cover-07-17-2017.pdf

Arnold, V., Bedard, J. C., Phillips, J., \& Sutton, S. G. (2010). Where do investors prefer to find nonfinancial information? Journal of Accountancy. Retrieved from http://www.journalofaccountancy.com/Web/20102682.htm.

Bagai, E. (2010). Facts on How Oil Affects the Economy. Ehow. Demand Media. Retrieved from http://www.ehow.com/about_6529713_oil-affects-economy.html

Baker, H. E., \& Kare, D. D. (1992) Relationship Between Annual Report Readability and Corporate Financial Performance. Management Research News, 15(1), 1-4.

Barnett, A., \& Leoffler, K. (1979). Readability of Accounting and Auditing Messages. Journal of Business Communication, 16(3),49-59. Doi: 10.1177/002194367901600305.

Belkaoui, A. (1995). The Linguistic Shaping of Accounting. Westport, CT: Quorum Books.Bent

Buessing, M., \& Soto, M. (2006) The State of Private Pensions: Current 5500 data (Report No. 42). Chestnut Hill, MA: The Center for Retirement Research. Retrieved from http://dx.doi.org/10.2139/ssrn.908272.

Carr, S. P. (2010). NAIC Takes on Readability of Insurance Policies. Retrieved from http://insurancenewsnet.com.article.aspx?id-175751\&type=newswires\#.UimIr4bhecd.

Courtis, J. K. (1986). An Investigation into annual report readability and corporate risk return relationships. Accounting and Business Research, 16(64).

Cox, C. (2007). Speech by SEC Chairman: Closing Remarks to the Second Annual Corporate Governance Summit. USC Marshall School of Business. Los Angeles, CA.

Cude, B. J. (2010). Communicating Effectively to Consumers. Retrieved from https://www.naic.org/documents/committees_b_consumer_information_1008_brenda_cude_prese ntation.pdf.

Dyckman, T. R., Dukes, R. E., \& Davis, C. J. (1995). Intermediate Accounting, $3^{\text {rd }}$ Edition. Chicago, IL: Irwin.

Employee Benefit Research Institute. (1996). The Reality of Retirement Today: Lessons in Planning for Tomorrow. Issue Brief. Retrieved from https://www.ebri.org/docs/default-source/ebri-issuebrief/0197ib.pdf?sfvrsn=8ae1292f_0

Financial Accounting Standards Board. (1985). Statement of Financial Accounting Standards (No. 87). Financial Accounting Foundation, Norwalk, CT.

Financial Accounting Standards Board. (1978). Statement of Financial Accounting Concepts no. 1: Objectives of Financial Reporting by Business Enterprises. Stanford, CT. FASB.

Financial Accounting Standards Board. (2016, March 11). Disclosure Framework-Entity's Decision Process. Retrieved from http://www.fasb.org/jsp/FASB/FASB Content C/ProjectUpdatePage\&cid $=1176163077122$

Flesch, R. (1949). The Art of Readable Writing. New York: Harper. 
General Motors. (1994). Annual Report 10-k. Retrieved from http://www.gm.com/content/dam/gmcom/COMPANY/Investors/Stockholder_Information/PDFs/ 2011_GM_Annual_Report.pdf.

Gifford, S. (2007). National endowment of the arts announces new reading study. National Endowment of the Arts. Retrieved from http://www.nea.gov/news /news07 /TRNR.html.

Griswold, J. (2008). Whatever Happened to Reading for Fun? Words Alive: Advocates for Reading. Retrieved from http://www.wordsalive.org/literacyfacts.html.

Hansen, D. D. (n.d.) Specifics of Insurance Law. Legal Career Information You Can Use. Retrieved from http://www.lawcrossing.com/article/150/Specifics-of-law/\#.

How to choose a stock, (2011). MarketWatch. Retrieved https:/www.marketwatch.com/story/how-to choose-a-stock-1305567953708

Jones, M. J., \& Shoemaker, P. A. (1994). Accounting Narratives: A Review of Empirical Studies of Content and Readability. Journal of Accounting Literature, 13.

Kimmel, P. D., Weygandt, J. J., \& Kieso, D. E. (2009). Accounting: Tools for Business Decision Making. Danvers, MA: John Wiley \&Sons, Inc.

Kincaid, J. P., Fishburne, R. P., Rogers, R. L., \& Chissom, B.S. (1975). Derivation of New Readability Formulas (Automated Readability Index, Fog Count, and Flesch Reading Ease formula) for Navy Enlisted Personnel. Research Branch Report, 8-75. Chief of Naval Technical Training: Naval Air Station Memphis.

King, E. C. (1947, September 5). Footnotes to Financial Statements, Address of to the Virginia Society of Public Accountants. Securities and Exchange Commission.

Kirsch I. S., Jungeblut A., Jenkins L., \& Kolstad A. (1993). Adult Literacy in America. National Center for Education Statistics. U. S. Department of Education. Washington, D.C.

Know Your Readers. (n.d.). Plain Language at Work Newsletter. Retrieved from http://www.impactinformation.com/impactinfo/literacy.htm.

Kutner, M., Greenberg, E., Jin, Y., Boyle, B., Hsu, Y., \& Dunleavy, E. (2007). Literacy in Everyday Life: Results From the 2003 National Assessment of Adult Literacy (NCES 2007-480). U.S. Department of Education. Washington, DC: National Center for Education Statistics.

Li, F. (2006). Annual Report Readability, Current Earnings, and Earnings Persistence. University of Michigan Working Paper.

Marshall, D. H. (1993). A Survey of Accounting: What the Numbers Mean? $3^{\text {rd }}$ edition Burr Ridge, IL: Irwin.

McCarthy, D. D., \& Turner J. A. (2000). Pension Education: Does it Work? Does It Matter? Benefits Quarterly, First Quarter.

National Association of Insurance Commissioners. (2016). Transparency and readability of consumer information working group. Retrieved from http://www.naic.org/committees_c_trans_read_wg.htm

National Commission on Adult Literacy. (2008). Reach Higher, America Overcoming Crisis in the U.S. Workforce. Retrieved from http://www.nationalcommissiononadultliteracy.org/ReachHigherAmerica/ReachHigher.pdf.

Paasche-Orlow, M. K., Taylor, J. A., \& Brancati, F. L. (2003). Readability standards for informedconsent forms as compared with actual readability. New England Journal of Medicine, 348, 721726.

Plain Language Initiative. (n.d). The Truth About Literacy in the United States. (n.d.). Prophet, Incorporated: The Future of Education. Retrieved http:/www.prophet-inc.com/literacy.html.

Prater, C. (2010, July 22). U.S. Credit Card Agreements Unreadable to 4 Out of 5 Adults. Retrieved from http://www.creditcards.com/credit-card-news/ credit-card-agreementreadability1282.php.

Public Writing Act of 2010, 124, Public L. No 124-274, 124 STAT. 2861. (2010). Retrieved from http://www.gpo.gov/fdsys/pkg/PLAW-111 publ274/pdf/PLAW-111publ274.pdf. 
Read Financial Footnotes, Invest Safely. (2008, November 28). Retrieved from http://www.gurufocus.com/news/39182/read-financial-footnotes-invest-safely.

Schneider, D. E. (n.d.). Assessing the readability of college textbooks in public speaking: attending to entry level instruction Texas Office of Consumer Credit Commissioner. Plain language initiative.

Retrieved from https://occc.texas.gov/industry/plain-language-initiative

Shapiro, R. J., \& Pham, N. D. (2014). Who owns America's oil and natural gas companies: a 2014 update. Sonecon. Retrieved from https://www.sonecon.com/docs/studies/Who_Owns_Americas_Oil_and_Natural_Gas_Companies -Shapiro-Pham-October2014.pdf

Smith, J. E., \& Smith, N. P. (1971). Readability: A Measure of the Performance of the Communication Function of Financial Reporting. The Accounting Review, 46(3) 551-562.

Subramanian, R., Insley, R. G., \& Blackwell, R.D. (1993). Performance and Readability: A Comparison of Annual Reports of Profitable and Unprofitable Corporations. Journal of Business Communication, 30(1), 49-61. Doi: 10.1177/002194369303000103.

The Princeton Review. (n.d.) Career: Financial analyst. Retrieved from http://www.princetonreview.com /careers.aspx? cid $=68$.

U.S. Securities and Exchange Commission. (1998). A Plain English Handbook: How to Create Clear SEC Disclosure Documents. U.S. Securities and Exchange Commission: Washington, DC. U.S. Securities and Exchange Commission. (n.d.). Division of Corporation of Finance: Standard Industrial Classification (SIC) code list. Retrieved from http://www.sec.gov/info/edgar / siccodes.htm.

U.S. Department of Labor, Pension, and Welfare Benefits Administration. (1994). Pension and Health Benefits of American Workers. Washington D. C.

Wayman, R. (2008). An Investor's Checklist to Financial Footnotes. Investopedia. Retrieved from http://www.investopedia.com/articles/analyst/03/100103.asp\#axzz2Ae6WfjY8.

Werntz, W. W. (1939). Securities and Exchange Commission, Footnotes and Financial Statements, Address to the Minnesota Statistical Association and The Minnesota Society of Certified Public Accountants.

Winslow, E. H., \& Jacobson, A. F. (1998). According to Research for Practice. The American Journal of Nursing, 98(7) 55-57. 